\title{
Proposal of quantitative and qualitative metrics to assess affective user-centered design of video games
}

\author{
Elison Ribeiro \\ Universidade Federal do Pará \\ Belém, Brazil \\ elisonhbribeiro@gmail.com
}

\author{
Marcos Seruffo \\ Universidade Federal do Pará \\ Belém, Brazil \\ seruffo@ufpa.br
}

\begin{abstract}
The experience which emerges from digital games has, above all, an emotional nature, so evaluating the user experience only through objective factors does not seem to be sufficient for the analysis of a game as it is an entertainment product. This article intends to propose a set of metrics that allow evaluating affective, or roughly speaking, emotional aspects of the user experience from digital games. The metrics are applied to a list, found in a related work, of relevant game design components that affect the subjective experience of gaming. The intended experiment in the future is a gameplay session of a game especially designed to include a system that measures in background, through the proposed metrics, players' actions in the gaming experience. The result in this paper is a set of quantitative and qualitative metrics that will assess players' choices in the actual experiment and that yield numerical outcomes, even though the analyzed factors are subjective.
\end{abstract}

\section{Author Keywords}

User experience; Digital games; Affective; Game design; Quantitative; Qualitative; Metrics.

\section{ACM Classification Keywords}

H.5.m. Information interfaces and presentation (e.g., HCI): Miscellaneous; See http://acm.org/about/class/1998 for the full list of ACM classifiers. This section is required.

\section{INTRODUCTION}

For the video game industry, finding good practices of usercentered design is extremely interesting as it can prevent costs from the addition of features that players could ignore or even reject. However, when user experience is applied in computer and video games, although they are digital products, the evaluation cannot be about objective metrics only, since a videogame is an entertainment software which provides a subjective, affective experience [3]. To evaluate affective user-centered design (AUCD) of digital games,

\footnotetext{
Permission to make digital or hard copies of all or part of this work for personal or classroom use is granted without fee provided that copies are not made or distributed for profit or commercial advantage and that copies bear this notice and the full citation on the first page. Copyrights for components of this work owned by others than the author(s) must be honored. Abstracting with credit is permitted. To copy otherwise, or republish, to post on servers or to redistribute to lists, requires prior specific permission and/or a fee. Copyright 2018 SBC.

IHC 2018, Anais Estendidos do XVII Simpósio Brasileiro sobre Fatores Humanos em Sistemas Computacionais

Outubro 22-26, 2018, Belém, Brasil

PÔSTERES VIRTUAIS E DEMOS
}

this paper presents two complementary methods. For one of which to be carried out, a game is going to be especially designed with different features to include various metrics which are the focus of this work.

\section{RELATED WORK}

The affective game design components that will be assessed along this experiment are all listed and somewhat extensively discussed in the research article by $\mathrm{Ng}$ et al. [1]. After interviews and observations of a gameplay session, the researchers collected feedback to determine the most relevant game design components, as shown in the left column of Table 1, along with other recommendations based also on the literature.

The above-mentioned game design components were mapped against other five previews works. One of those is the paper by Desurvire et al. [2], that provides a quite large set of what they call "Heuristic Evaluation for Playability" (HEP), which are guidelines for game design based on the literature at that time, reviewed by a group of game design professionals. The authors have performed a playtest session with four participants who also took a satisfaction questionnaire. Some of the resulting recom-mendations are employed in this work as evaluation metrics.

\section{METHODS}

Usability is the capability of a user to accomplish the task that the product is meant to carry out, that is, an objective attribute [3]. So, for the game industry, usability is essential, but not sufficient to assess the user experience of a product as a whole, since it deals with pleasure and emotions, or, in other words, with affect [3]. By observing the list proposed by $\mathrm{Ng}$ et al. [1] shown in the left column of Table 1, it is reasonable to say that much of the subjective experience from games is based on options, i.e., features whose usage can be customized or measured in some way. Thus, the players' choices, both before and during the game, can be monitored in background so it does not interrupt the game's flow. This special aspect is what this article makes use of to propose quantitative metrics.

Two types of complementary methods will be carried out with participation of users to assess their gaming experience. The first evaluation, for the qualitative metrics, is an electronic multiple choice survey in search for players' major preferences on creative content of games that are impracticable to be measured quantitatively, such as style and graphics. For that phase, users will choose 
between images that best answer questions on preferences, and then the results will be counted. The second method, for the quantitative metrics, takes place during a gameplay session. It is an automatic in-background track of players' actions and reactions in a gaming experience towards several options and situations deliberately added to it. The idea is to evaluate ten groups of five individuals, divided per age range and gender, in order to learn each audience's behaviors and preferences on the affective game design components highlighted in [1], through purely numerical indicators from within the videogame, with no human observation, as in the related works, nor bio-signal processing. The game for the playtest is yet to be designed, but due to artistic limitations and in order to comprehend the metrics proposed here, it will probably be a short 2DRPG-adventure game. This style is just convenient as it allows a story and quantifiable attributes for the characters.

\section{RESULTS AND DISCUSSION}

The aim of this paper is to come up with a set of mechanical elements of a digital game that allow a quantitative assessment of affective components of game design proposed in [1] by means of a gaming experience especially designed for such purpose. Although a survey is recognized as a qualitative evaluation since the participants' answers are based on their subjective judgment, it will result in numerical outcomes. The final proposal is in the right column of Table 1 . Some metrics are indicated as "survey". The other ones, though, are considered to be quantitative because the numbers will be found out by automatically measuring numerical factors, such as frequency and duration of in-game actions. The metrics are suggestions based on a simple logic: variables that are apparently related to the game design components and that can be automatically monitored or, otherwise, surveyed.

\begin{tabular}{|c|c|}
\hline $\begin{array}{l}\text { Affective game } \\
\text { design } \\
\text { components }\end{array}$ & Metrics \\
\hline Challenge & $\begin{array}{l}\text { Chosen game difficulty; current state } \\
\text { when quitting the game }\end{array}$ \\
\hline $\begin{array}{l}\text { Pacing } \\
\text { difficulty }\end{array}$ & $\begin{array}{l}\text { Difficulty after skipping a } \\
\text { level/mission; }\end{array}$ \\
\hline Clear goals & $\begin{array}{l}\text { Time before seeking in-game } \\
\text { instruction; frequency of side quests }\end{array}$ \\
\hline $\begin{array}{l}\text { Player's } \\
\text { capability }\end{array}$ & Repetition of failures; use of cheats \\
\hline Special rewards & $\begin{array}{l}\text { Search for aesthetic rewards; sacrifice } \\
\text { for power or easiness }\end{array}$ \\
\hline $\begin{array}{l}\text { Interactive } \\
\text { environment }\end{array}$ & $\begin{array}{c}\text { Frequency of interactions with dynamic } \\
\text { environment; interactions on loading } \\
\text { screen }\end{array}$ \\
\hline $\begin{array}{l}\text { AI actors } \\
\text { interaction }\end{array}$ & $\begin{array}{l}\text { Actions towards actors of different in- } \\
\text { game level of importance }\end{array}$ \\
\hline Graphic quality & Survey: preference on graphic quality \\
\hline
\end{tabular}

\begin{tabular}{|c|c|}
\hline $\begin{array}{c}\text { Affective game } \\
\text { design } \\
\text { components }\end{array}$ & Metrics \\
\hline Creativity & Survey: preference on familiarity \\
\hline Fantasy & Survey: preference of world type \\
\hline Storyline & Amount of story skipped or searched \\
\hline Characters & Dedication to customize avatar \\
\hline $\begin{array}{l}\text { Range of } \\
\text { options }\end{array}$ & Record of settings customization \\
\hline $\begin{array}{l}\text { Non-interactive } \\
\text { content }\end{array}$ & Frequency of skipping such content \\
\hline Interruption & Players' settings for secondary info \\
\hline Not lagging & Sacrifices for higher frame rates \\
\hline $\begin{array}{l}\text { Organized } \\
\text { menus }\end{array}$ & $\begin{array}{c}\text { Menu interface preferences; frequency } \\
\text { of use of popup texts }\end{array}$ \\
\hline Tutorial & Rate of skipping or resuming tutorials \\
\hline $\begin{array}{l}\text { Unobtrusive } \\
\text { view }\end{array}$ & $\begin{array}{c}\text { Survey: preferences on camera angle; } \\
\text { Use of custom interfaces }\end{array}$ \\
\hline $\begin{array}{l}\text { Help for stuck } \\
\text { players }\end{array}$ & $\begin{array}{l}\text { Time before seeking answers; sacrifice } \\
\text { for answers }\end{array}$ \\
\hline Control System & $\begin{array}{l}\text { Survey: preferences on physical } \\
\text { control; control setting preferences }\end{array}$ \\
\hline
\end{tabular}

Table 1. Affective game design components with proposed metrics.

\section{CONCLUSION AND FUTURE WORK}

In the list of relevant game design components found out by $\mathrm{Ng}$ et al. [1], there was no item regarding sound or music in the gaming experience, so additional metrics about that aspect can be considered in future analyses. Other metrics will certainly be added to Table 1 by the time of the actual experiment. Finally, automatic measurements can be an extra tool for the industry to assess the relevance of some games' features and to assure more quality to the products after the playtesting stage.

\section{REFERENCES}

1. Yiing Y'ng Ng, Chee Weng Khong, and Robert Jeyakumar Nathan. 2018. Evaluating Affective UserCentered Design of Video Games Using Qualitative Methods. International Journal of Computer Games Technology 2018: 1-13. https://doi.org/10.1155/2018/3757083

2. Heather Desurvire, Martin Caplan, and Jozsef A. Toth. 2004. Using heuristics to evaluate the playability of games. In Extended abstracts of the 2004 conference on Human factors and computing systems (CHI '04). https://doi.org/10.1145/985921.986102

3. André F. da Costa. 2016. Avaliação de experiência de jogador aplicada ao desenvolvimento de jogos. Master Thesis. Escola Politécnica da Universidade de São Paulo, São Paulo, SP, Brazil. 